\title{
ALOKASI TENAGA KERJA RUMAHTANGGA TANI PENERIMA BANTUAN MODAL TERNAK SAPI DI KECAMATAN KAWANGKOAN BARAT
}

\author{
Mardy Tendean, S.J.K. Umboh*, E. Wantasen, F. H. Elly.
}

\author{
Fakultas Peternakan Universitas Sam Ratulangi Manado, 95115
}

\begin{abstract}
ABSTRAK
Penelitian ini bertujuan untuk menganalisis alokasi tenaga kerja keluarga rumahtangga tani penerima bantuan modal ternak sapi di Kecamatan Kawangkoan Barat Kabupaten Minahasa. Penelitian ini menggunakan metode survei pada 30 rumahtangga tani sampel. Pengambilan data dilakukan pada bulan September sampai November 2018. Sumber data yakni data primer dan data sekunder. Data primer diperoleh dari hasil wawancara langsung dengan responden. Data sekunder diperoleh dari Dinas Pertanian dan Peternakan Kabupaten Minahasa, instansi yang terkait dengan kebutuhan. Metode analisis menggunakan pendekatan ekonometrika dengan model persamaan simultan dan dianalisis dengan software SAS 9.4. penelitian Alokasi tenaga kerja keluarga untuk usaha ternak sapi mencapai 49.36\% dari total curahan tenaga kerja pada berbagai aktivitas usaha tani. Curahan tenaga kerja pria lebih mendominasi dalam pengalokasian tenaga kerja tersebut, alokasi tenaga kerja keluarga pada kegiatan usaha ternak sapi terbesar pada kegiatan mencari dan memberi makan ternak sapi yakni sebesar 45.80\%, diikuti kegiatan menggembalakan/ikat pindah sapi dan membersihkan kandang dan mengangkat kotoran masing-masing sebesar $34.92 \%$ dan $18.39 \%$.
\end{abstract}

Kata Kunci : Rumahtangga, bantuan modal, alokasi, tenaga kerja

\footnotetext{
*Korespondensi (corresponding author): e-mail: (sintyajkumboh@yahoo.co.id)
}

\section{ABSTRACT}

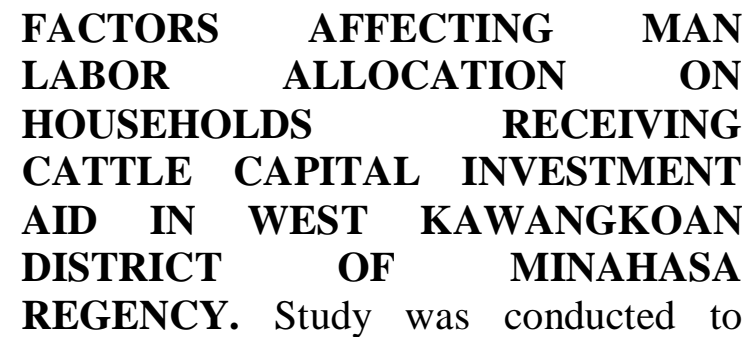
analyze factors affecting man labor allocation on households receiving cattle capital investment aid in west kawangkoan district of minahasa regency. Study was done by survey method involving 30 samples of household farmers during September to November 2018. The specific model was applied with the household economic model in form of simultaneous regression system. Involving man labor at household was significantly affected by labor cost, amount of involving woman labor at household, amount of capital aid allocation for cattle farm, amount of cattle sold, and amount of household income. Household farmers positively gave response by doing allocation of man labor for cattle farm at household in the increasing occurrence of labor cost, capital aid and household income.

Keywords : Household, capital aid, labor 


\section{PENDAHULUAN}

Rumahtangga tani bertindak sebagai produsen dan sekaligus sebagai konsumen yang memaksimumkan kepuasan atau utilitas dan mendapatkan keuntungan atau profit dari kegiatan produksi usaha taninya. Peningkatan produksi berdampak pada meningkatnya pendapatan rumahtangga peternak, sehingga meningkatkan pengeluaran konsumsi rumahtangga. Dengan demikian keputusan konsumsi tergantung pada besarnya pendapatan yang diperoleh dari kegiatan produksi (deRosari et al., 2014; Umboh et al., 2014). Salah satu kebijakan pemerintah yang dapat meningkatkan pendapatan petani melalui perbaikan produksi dan peningkatan konsumsi yakni kebijakan pemberian bantuan modal. Kebijakan pemberian bantuan modal dalam meningkatkan pendapatan dan kesejahteraan petani telah dibuktikan di berbagai negara terutama di negara-negara berkembang (Nuryartono et al., 2005; Adebayo et al., 2008) Bantuan modal adalah modal usaha yang diberikan oleh pihak lain (pemerintah dan non pemerintah) kepada rumahtangga tani baik dalam bentuk tunai atau natura dengan maksud untuk meningkatkan kegiatan produksi. Untuk keperluan analisis, maka bantuan modal ini dinilai dalam nilai tertentu yang disesuaikan dengan nilai/harga pada saat bantuan modal diberikan. Bantuan modal produksi dapat digunakan untuk pengeluaran lainnya karena bantuan modal dianggap sebagai salah satu sumber untuk menjaga likuiditas keuangan rumahtangga. Penelitian yang dilakukan oleh Yasmeen et al. (2011) di Pakistan bahwa pemberian bantuan modal oleh pemerintah setidak-tidaknya dapat meningkatkan standar hidup rumahtangga pertanian, terutama dalam empat sektor, yakni kenaikan konsumsi listrik dan barang elektronik, peningkatan pendidikan anak, peningkatan penggunaan jasa transportasi dan aset, serta peningkatan konsumsi makanan dan kesehatan. Misalnya di Indonesia walaupun pangsa bantuan modal untuk sektor pertanian kecil, namun petani memiliki kearifan dalam menggunakan bantuan modal tersebut yang tidak untuk usaha tani semata. Modal tersebut juga dimanfaatkan untuk kegiatan non usaha tani yang menunjang ekonomi rumahtangga.

Rumahtangga tani memiliki sejumlah sumber daya yang terbatas jumlahnya, dan membuat keputusan untuk mencapai ekuilibrium tertentu yang merupakan tingkat kepuasannya dengan menggunakan sumber daya tersebut. Rumahtangga tani dalam mencapai tujuan memaksimumkan kepuasan dapat memproduksi satu unit produk (single product) atau memproduksi berbagai produk (multiple products) untuk langsung 
dikonsumsi atau sebagian dijual untuk memenuhi kebutuhannya. Dalam memproduksi misalnya tanaman pangan atau ternak rumahtangga tersebut dapat mengupah tenaga kerja dari luar keluarga atau bekerja sendiri tergantung tipe rumahtangga subsisten atau semi subsisten dan dapat menjual tenaga kerja keluarga keluar untuk memperoleh pendapatan ( Derosari et al., 2014). Rumahtangga tani dalam hal ini dipandang sebagai satu unit ekonomi, dalam pengambilan keputusan mengalokasikan sumberdayanya (tenaga kerja, modal, dan waktu) diarahkan untuk aktivitas dibidang produksi.

Masyarakat di lokasi penelitian ini sebagian besar usaha peternakan dengan sistem pemeliharaan secara tradisional dan hanya memanfaatkan anggota keluarga sebagai tenaga kerja. Tenaga kerja keluarga yang biasanya digunakan dalam usaha peternakan rakyat terdiri dari ayah (kepala keluarga), ibu dan anak-anak. Beberapa hasil penelitian menunjukkan bahwa kepala keluarga memiliki curahan waktu kerja yang lebih besar dibandingkan dengan anggota keluarga lainnya. Hal ini disebabkan karena istri lebih sibuk mengurus rumah tangga dan mengasuh anak, sedangkan anak-anak harus bersekolah (Tatipikalawan, 2012)

Usaha ternak sapi di Kecamatan Kawangkoan Barat didominasi oleh usaha skala kecil, sehingga penggunaan tenaga kerja dalam keluarga masih berperan penting dalam pengelolaan usaha ternak sapi. Petani peternak umumnya telah berpengalaman memelihara sapi. Ratarata pengalaman beternak sapi untuk petani peternak selama 15 tahun. Pengalaman beternak sapi ini mempengaruhi keputusan berproduksi bagi petani peternak. Diduga semakin lama beternak sapi maka petani peternak dapat meningkatkan produksi ternak sapi. Awal mulai beternak, sebagian petani peternak memperoleh bibit sebagai warisan orangtua, sebagian sebagai warisan dan beli sendiri. Sebagian petani peternak membeli sendiri ternaknya sebagai bibit atau bibit diperoleh dengan cara ditukar misalnya ditukar kebun. Berdasarkan kondisi tersebut dapat dinyatakan bahwa usaha ternak yang ada merupakan usaha ternak yang diusahakan secara turun-temurun. Tahun 2017 populasi ternak sapi di Kecamatan Kawangkoan Barat sebanyak 2.348 ekor, menempati urutan kedua setelah populasi ternak babi.

Kecamatan Kawangkoan Barat merupakan salah satu kecamatan penerima bantuan modal di Kabupaten Minahasa. Pemberian bantuan bantuan modal oleh pemerintah (dana APBN) dilakukan Tahun 2014 dan 2015 melalui 2 (dua) kegiatan yakni: (1) Budidaya Sapi Potong dan (2) Integrasi Sapi Potong dengan Tanaman. Pemberian bantuan ternak sapi melalui 
kegiatan budidaya sapi potong diberikan pada Kelompok Tani Karondoran, sedangkan pemberian bantuan ternak sapi melalui kegiatan integrasi sapi potong dengan tanaman diberikan pada Kelompok Tani Esa Ate.

Umumnya dalam pemeliharaan ternak sapi peternak melibatkan seluruh anggota keluarga. Pengelolaan ternak sapi dalam hal ini menjadi bagian pekerjaan anggota keluarga. Sejalan dengan kondisi tersebut, maka dalam upaya meningkatkan produksi dan pendapatan keluarga, tenaga kerja memegang peranan penting. Kualitas dan kuantitas tenaga kerja yang digunakan dalam kegiatan usaha ternak sapi memberikan dampak terhadap keberhasilan usaha. Faktor produksi tenaga kerja merupakan faktor produksi yang penting dan perlu diperhitungkan dalam proses produksi dalam jumlah yang cukup, bukan saja dilihat dari tersedianya tenaga kerja tetapi juga kualitas dan macam tenaga kerja. Berdasarkan hal tersebut diperlukan suatu analisis untuk mengetahui alokasi tenaga kerja dan faktor-faktor yang mempengaruhi alokasi tenaga kerja rumahtangga petani penerima bantuan modal untuk usaha ternak sapi di Kecamatan Kawangkoan Barat.

\section{METODE PENELITIAN}

Penelitian menggunakan metode survei. Pengumpulan data menggunakan teknik wawancara pada responden rumahtangga tani peternak sapi penerima bantuan modal ternak sapi dengan menggunakan kuesioner yang telah disiapkan. Penelitian ini dilaksanakan di Kecamatan Kawangkoan Barat Kabupaten Minahasa. Waktu pelaksanaan bulan September sampai November 2018.

Jenis data yang dikumpulkan merupakan data cross section (data pada satu titik waktu tertentu). Sumber data yakni data primer dan data sekunder. Data primer diperoleh dari hasil pengamatan dan hasil wawancara langsung dengan responden. Data primer dikumpulkan antara lain, karakteristik petani dan curahan waktu kerja petani dalam usaha ternak sapi, jumlah ternak sapi yang dipelihara oleh responden. Data sekunder diperoleh dari Dinas Pertanian dan Peternakan Kabupaten Minahasa, dan Badan Pusat Statistik (BPS) Sulawesi Utara, dan instansi lain yang terkait dengan kebutuhan penelitian, serta data hasil penelitian yang dipublikasi (Sinaga, 2011).

Penentuan sampel lokasi dilakukan dengan menggunakan metode purposive sampling yaitu penentuan dengan pertimbangan tertentu. Desa Kanonang Lima ditentuan dengan pertimbangan: (1) salah satu sentra populasi sapi di Kabupaten Minahasa dan (2) penerima bantuan ternak sapi terbanyak di 
Kecamatan Kawangkoan Barat Kabupaten Minahasa. Penentuan sampel petani ditentukan secara pursposive sampling yaitu populasi rumahtangga peternak sapi yang menerima bantuan modal untuk usaha ternak sapi. Penentuan rumahtangga responden adalah rumahtangga petani penerima bantuan modal yang telah menjual sapi bantuan.

\section{HASIL DAN PEMBAHASAN}

\section{Keadaan Umum Wilayah dan Lokasi Penelitian}

Kabupaten Minahasa merupakan salah satu kabupaten di Provinsi Sulawesi Utara. Ibukota Kabupaten Minahasa yakni Tondano, berjarak sekitar $35 \mathrm{Km}$ dari Manado, ibukota Propinsi Sulawesi Utara. Adapun batas-batasnya adalah sebagai berikut :

- Sebelah utara dengan Laut Sulawesi dan Kabupaten Sangihe Talaud;

- Sebelah timur dengan laut Maluku dan Kota Bitung;

- Sebelah selatan dengan Kabupaten Bolaang Mongondow;

- Sebelah barat dengan laut Sulawesi dan Kota Manado.

Luas Kabupaten Minahasa adalah $4.168 \mathrm{Km}^{2}$ dan terletak antara : $0^{0} 25$ $1^{0} 58$ Lintang Utara dan $124^{0} 58$ Lintang Utara dan $124^{0} 20-125^{0} 20$ Bujur Timur. Kabupaten Minahasa terdiri dari 30 Kecamatan. Kecamatan terluas yakni Kecamatan Tombatu (32.010 Ha), sedangkan kecamatan dengan luasan terkecil yakni Kecamatan Tompaso (3.020 Ha). Daerah yang beriklim tropis ini hanya mengenal 2 musim yaitu musim kemarau dan musim penghujan. Kelembaban udara relatif tinggi berkisar rata-rata antara 75 sampai 97 persen, sedangkan rata - rata suhu minimum dan maksimum antara 18.2 dan 27.9 derajat celcius.

Kecamatan Kawangkoan Barat merupakan dataran rendah dengan ketinggian rata-rata +84 meter di atas permukaan laut, terletak pada posisi $1^{\circ} 20^{\prime} 0.25 \mathrm{~N}$ (Lintang Utara) dan 1247'ㄱ.3"E (Bujur Timur). Luas Kecamatan Kawangkoan Barat yakni $19,27 \mathrm{~km} 2$ atau $1.87 \%$ dari luas Kabupaten Minahasa. Akhir tahun 2017, wilayah administrasi Kecamatan Kawangkoan terdiri dari 10 wilayah desa, yaitu: Sendangan, Kinali, Tondegesan, Kanonang Tiga, Sendangan Selatan, Sendangan Tengah, Uner Satu, Kinali Satu, Tondegesan Satu, Tondegesan Dua. Ibukota Ibukota Kecamatan Kawangkoan Barat yakni Desa Kayuuwi, berjarak sekitar $28 \mathrm{~km}$ dari Tondano, ibukota Kabupaten Minahasa.

\section{Karakteristik Rumahtangga Petani} Usaha Ternak Sapi

Karakteristik rumahtangga menyangkut karakteristik kepala keluarga maupun ibu rumahtangga responden di Kecamatan Kawangkoan Barat. 
Karakteristik rumahtangga petani peternak sapi tersebut dapat dilihat pada Tabel 1 .

Karakteristik rumahtangga sangat penting dipelajari karena dapat mempengaruhi perilaku ekonomi rumahtangga, dengan kata lain karakteristik rumahtangga dapat mempengaruhi keputusan produksi dan keputusan konsumsi. Keputusan produksi termasuk bagaimana keputusan mengalokasikan tenaga kerja untuk memperoleh pendapatan. Pendapatan yang diperoleh dialokasikan untuk pengeluaran konsumsi rumahtangga baik konsumsi pangan maupun non pangan.

Rata-rata umur responden (Kepala Keluarga) 45 tahun. Sedangkan rata-rata umur ibu rumahtangga 42 tahun. Hal ini mengindikasikan bahwa responden dikategorikan usia produktif. Tingkat pendidikan petani peternak sebagai kepala keluarga maupun ibu rumahtangga mulai dari tidak tamat SD sampai dengan tamat Perguruan Tinggi dengan rata-rata lama pendidikan sebesar 9 tahun. Pendidikan merupakan hal yang penting dalam meningkatkan ketrampilan dan kemampuan peternak. Melalui pendidikan manusia diberi kesempatan untuk mengembangkan kemampuannya dan membina usaha yang dibidanginya. Demikian halnya tingkat pendidikan berpengaruh bagi petani/peternak dalam mengelola usaha peternakan dan setidaknya merupakan salah satu faktor yang mempengaruhi keberhasilan usaha. Semakin tinggi tingkat pendidikan diharapkan pola berpikir semakin rasioanl. Pendidikan petani peternak merupakan faktor yang mempengaruhi pengembangan usaha ternak sapi. Dalam hal ini, pendidikan dapat mempengaruhi keputusan produksi. Semakin tinggi pendidikan, petani peternak semakin dapat mengadopsi teknologi. Selanjutnya petani peternak dapat meningkatkan produksi dengan rasional untuk mencapai keuntungan maksimal.

Petani peternak sebagai kepala keluarga umumnya telah berpengalaman memelihara sapi. Rata-rata pengalaman beternak sapi untuk petani peternak sebesar 15 tahun. Pengalaman beternak sapi ini juga dapat mempengaruhi keputusan berproduksi bagi petani peternak. Diduga semakin lama beternak sapi maka petani peternak dapat meningkatkan produksi ternak sapi. Hasil penelitian menunjukkan bahwa pada awal mulai beternak, sebagian petani peternak memperoleh bibit sebagai warisan orangtua. Sebagian petani peternak membeli sendiri ternaknya sebagai bibit atau bibit diperoleh dengan cara ditukar misalnya ditukar kebun. Berdasarkan kondisi tersebut dapat dinyatakan bahwa usaha ternak yang ada merupakan usaha ternak yang diusahakan secara turun-temurun. 
Rata-rata jumlah anggota keluarga sebanyak 4 orang, Jumlah anggota keluarga anak sekolah (rata-rata 1 orang). Jumlah anggota keluarga dapat mempengaruhi keputusan produksi maupun keputusan konsumsi.

Penelitian ini juga mengkaji kondisi sosial dari petani peternak. Kondisi ini perlu diperhatikan karena berkaitan dengan peningkatan kesejahteraan rumahtangga petani peternak sapi, dengan anggapan kondisi tersebut sebagai penunjang tingkat pendapatan maupun pengeluaran rumahtangga petani peternak sapi. Sebagian besar tanah pekarangan dan rumah merupakan milik rumahtangga petani peternak (50\%). Sisanya $50 \%$ adalah milik orang tua atau lainnya. Sebagian besar petani peternak sapi sudah menggunakan listrik dalam arti mempunyai meteran listrik.

\section{Alokasi Tenaga Kerja Keluarga}

Secara teori, tenaga kerja rumahtangga tani dialokasikan untuk kegiatan di usaha tani, kegiatan di pasar tenaga kerja di luar rumah untuk mendapatkan pendapatan, kegiatan dalam rumah untuk pekerjaan rumahtangga, dan konsumsi waktu luang (Becker, 1976; Ellis, 1988). Alokasi tenaga kerja keluarga dalam penelitian ini diukur dari penawaran tenaga kerja keluarga pada usaha ternak sapi dan usaha tani selain sapi. Alokasi tenaga kerja untuk kegiatan dalam rumahtangga dan konsumsi waktu luang tidak dihitung. Tabel 2 menunjukkan bahwa rata-rata curahan tenaga kerja keluarga pada usaha ternak sapi selama 1 tahun yaitu 504.47 HOK yang terbagi dalam jumlah alokasi tenaga kerja pria sebanyak 393.97 HOK dari jumlah alokasi tenaga kerja wanita sebanyak 110.50 HOK. Sedangkan rata-rata curahan tenaga kerja keluarga pada usaha tani selain sapi berjumlah 517.35 HOK terdiri atas 296.97 HOK kontribusi tenaga kerja pria dan 220.38 HOK kontribusi tenaga kerja wanita. Secara keseluruhan rata-rata curahan tenaga kerja keluarga untuk usaha ternak sapi dan usaha tani selain sapi sebanyak 1021.82 HOK atau sebesar $49.36 \%$ teralokasi untuk usaha ternak sapi dan sisanya sebesar $50.63 \%$ untuk usahatani selan sapi.

Berdasarkan Tabel 4 diketahui bahwa alokasi tenaga kerja keluarga terbesar pada kegiatan mencari dan memberi makan ternak sapi yakni sebesar 47.83\%, diikuti kegiatan menggembalakan/ikat pindah sapi dan membersihkan kandang dan mengangkat kotoran masing-masing sebesar $33.26 \%$ dan $18.12 \%$. Hasil penelitian ini sejalan dengan Wantasen dan Hartono (2013). tentang alokasi waktu dan kontribusi kerja anggota rumah tangga menunjukkan bahwa curahan tenaga kerja pria dalam keluarga dalam kegiatan usaha ternak sapi 
lebih besar besar dibanding tenaga kerja wanita. Hasil ini menunjukkan juga bahwa faktor lokasi dan jenis status dalam keluarga cenderung mencerminkan perbedaan respon mencari nafkah. Dalam hal curahan jam kerja, maka ada kecenderungan perbedaan nilai relatif kontribusi kerja anggota keluarga menurut status dalam keluarga, jenis kelamin dan tipe desa (Elly et al., 2008).

Tabel 1. Karakteristik Rumahtangga Responden

\begin{tabular}{lc}
\hline Karakteristik Responden & Rata-Rata \\
\hline Rata-rata Umur (Tahun): & 48 \\
- Kepala Keluarga & 42 \\
- Ibu RT & \\
Rata-rata Pendidikan Formal (Tahun) : & 9 \\
- Kepala Keluarga & 9 \\
- Ibu RT & 15 \\
Rata-rata Pengalaman Usaha (Tahun) & 4 \\
Rata-rata jumlah Anggota keluarga (Orang) & \\
\hline
\end{tabular}

Tabel 2. Jumlah Alokasi Tenaga Kerja Keluarga pada Usaha Ternak Sapi dan Selain Sapi

\begin{tabular}{cccc}
\hline Alokasi (1 Tahun) & Pria & Wanita & Jumlah \\
\hline Usaha Ternak Sapi & 393.97 & 110.50 & 504.47 \\
Usaha Selain Sapi & 296.97 & 220.38 & 517.35 \\
\hline Jumlah & 690.94 & 330.88 & 1021.82 \\
\hline
\end{tabular}

Tabel 3. Persentase Alokasi Tenaga Kerja Keluarga pada Usaha Ternak Sapi dan Selain Sapi

Alokasi (1 Tahun) Pria+wanita $\quad$ Persentase (\%)

\begin{tabular}{lcc}
\hline Ternak Kerja Keluarga pada Usaha & 504.47 & 49.36 \\
Ternak Sapi (HOK) & & 50.63 \\
$\begin{array}{l}\text { Tenaga Kerja Keluarga Selain } \\
\text { Usaha Ternak Sapi (HOK) }\end{array}$ & 517.35 & 100 \\
\hline \multicolumn{1}{c}{ Jumlah } & 1021.82 & 100 \\
\hline
\end{tabular}


Tabel 4. Rata-rata Alokasi Tenaga Kerja Pria dan Wanita Dalam Keluarga Berdasarkan Kegiatan pada Usaha Ternak Sapi

\begin{tabular}{lccc}
\hline \multirow{2}{*}{ Jenis Kegiatan } & \multicolumn{2}{c}{ Alokasi Tenaga Kerja } & \multirow{2}{*}{ Jumlah } \\
& Keluarga $($ HOK) & \\
& Pria & Wanita & \\
\hline Mencari dan Memberi Makan Ternak Sapi & 228.73 & 3.04 & 231.77 \\
& $(58.05 \%)$ & $(3.35 \%)$ & $(47.83 \%)$ \\
Menggembalakan/Ikat Pindah Sapi & 112.08 & 49.1 & 161.18 \\
& $(28.44 \%)$ & $(54.25 \%)$ & $(33.26 \%)$ \\
Membersihkan Kandang dan Mengangkut & 49.73 & 38.09 & 87.82 \\
Kotoran & $(12.62 \%)$ & $(42.08 \%)$ & $(18.12 \%)$ \\
dan lain-lain & 3.43 & 0.27 & 3.7 \\
& $(0.87 \%)$ & $(0.29 \%)$ & $(0.76 \%)$ \\
\hline \multicolumn{1}{c}{ Jumlah } & 393.97 & 90.5 & 484.47 \\
& $(100 \%)$ & $(100 \%)$ & $(100 \%)$ \\
\hline
\end{tabular}

\section{KESIMPULAN}

1. Alokasi tenaga kerja keluarga untuk usaha ternak sapi mencapai $49.36 \%$ dari total curahan tenaga kerja pada berbagai aktivitas usaha tani. Curahan tenaga kerja pria lebih mendominasi dalam pengalokasian tenaga kerja tersebut.

2. Alokasi tenaga kerja keluarga pada kegiatan usaha ternak sapi terbesar pada kegiatan mencari dan memberi makan ternak sapi yakni sebesar 47.83\%, diikuti kegiatan menggembalakan/ikat pindah sapi dan membersihkan kandang dan mengangkat kotoran masing-masing sebesar $33.26 \%$ dan $18.12 \%$.

\section{DAFTAR PUSTAKA}

Adebayo, O.O., and R.G. Adeola. 2008. Sources and uses of agricultural credit by small scale farmers in surulere local government area of oyo state. Anthropologist. Journal. of Animal Science 10(4) : 313-314.

Becker, G.S. 1976. The economic approach to human behaviour. University of Chicago Press.

deRosari, B.B., B.M. Sinaga, N. Kusnadi dan M.H. Sawit. 2014. The impact of credit and capital supports on economic behavior of farm Households: a household economic approach. International Journal of Food and Agricultural Economics. 2 (3) : 81-90.

Elly, F.H., B.M. Sinaga, S.U. Kuntjoro dan N. Kusnadi. 2008. Pengembangan usaha ternak sapi rakyat melalui ontegrasi sapitanaman di Sulawesi Utara. Jurnal Litbang Pertanian 27(2) : 63-68.

Ellis, F. 1988. Peasant Economics : Farm households and agrarian 
development. Cambridge University Press, Cambridge, London.

Nuryartono, N., M. Zellerand and S. Schwarze. 2005. Credit rationing of farm households and agricultural production. Empirical evidence in the rural areas of central Sulawesi, Indonesia Tropentag StuttgartHohenheim, Proceedings. Conference on international agricultural research for development, University Hohenheim, Jerman, October 11-13, 2005. P. 1-8.

Sinaga, B. M. 2011. Metode Pengumpulan Data. Program studi ilmu ekonomi pertanian. Fakultas Ekonomi dan Manajemen. Sekolah pascasarjana, Institut Pertanian Bogor, Bogor.

Tatipikalawan, dan Jomina. 2012. Analisis produktiitas tenaga kerja keluarga pada usaha peternakan kerbau di pulau Moa Kabupaten Maluku Barat Daya. Skripsi. Jurusan peternakan fakultas pertanian Universitas Pattimura. Ambon.

Umboh, S. J. K., D. B. Hakim, B. M. Sinaga dan I. K. Kariyasa. 2014. Impact of domestic maize price changes on the performance of small scale broiler farming in Indonesia. Jurnal Media Peternakan 37(3) : 198205.

Wantasen, E. dan B. Hartono. 2013. Income upgrading model of cattlemen in Minahasa Regency, Indonesia. Sky Journal of Agricultural Research 2(3) : 20-27.

Yasmeen, K., S. Sarwar and T. Hussain. 2011. Government policy regarding agricultural loans and its impact upon farmers' standards of living in developing countries. Journal of Public Administration and Governance 1(1) : 2161-7104 